\title{
Vapaa sivistystyö kansallisen dialogin rakentajana
}

\author{
10 \\ Vapaan sivistystyön toimintamuodot ovat vuosisadan \\ aikana muuttaneet muotoaan. Dialogitaitojen opiskelulle \\ on jopa suurempi tarve kuin alkuaikoina.
}

ENSIMMÄISET TYÖVÄENOPISTOT ja kansalaisopistot syntyivät vähän yli sata vuotta sitten osana modernin kansallisvaltion muodostumista. Suomalaisen sivistysliikkeen snellmanilainen ideologia sisälsi ajatuksen, että kansakunnan tuli koostua sivistyneistä kansalaisista, jotka pystyisivät työskentelemään niin oman kuin kansankin hyvinvoinnin edistämiseksi. Sivistysajattelu lävisti käytännössä kaikki poliittiset liikkeet ja yhteiskuntaryhmät, joskin syyt ja perustelut vaihtelivat. Ensimmäisten opistojen perustamispäätöksissä korostuivat sivistysprojektin yleisten tavoitteiden lisäksi maininnat kansalaistaitojen kehittämisestä.

Modernisaation mukana kaupungistuminen ja teollistuminen etenivät valtavin harppauksin, ja pelkästään 1900-luvun vaihteessa kaupunkiväestön määrä kaksinkertaistui. Samalla Suomeen saapuivat uuden ajan poliittiset ideologiat - ja yhteiskunnalliset ongelmat.

Vuoden 1906 eduskuntauudistuksen mukana toteutunut yleinen ja yhtäläinen äänioikeus korosti kansalaistaitoja ja sivistystä alan keskusteluissa: kansalaisten tulisi pystyä käyttää äänioikeuttaan kansallisen hyvän edistämiseksi. Puhujan omasta taustasta riippui, mitä tämä käytännössä sitten tarkoitti.

Joka tapauksessa kaikkia ryhmiä yhdisti ajatus, että vapaan sivistystyön opistoissa tulisi olla laajemmat tavoitteet kuin vain oppilaiden tiedollisten valmiuksien parantaminen. Tarvittiin kansalaistaitoja, kykyä toimia ihmisenä ihmisten joukossa - eli sivistystä. Näin työväenopistojen ja kansalaisopistojen alkutaipaleen keskeisenä tavoitteena oli nimenomaan kasvattaa kansalliseen dialogiin pystyviä ja osallistuvia kansalaisia.

Miten opistot sitten käytännössä toteuttivat dialogia korostavaa sivistystehtäväänsä? Koska järjestelmä perustui vapaaehtoiseen osallistumiseen, siihen oli alkuaankin sisällytetty dialogin vaatimus. Sivistystehtävää ei voinut toteuttaa oppilaille vieraan ideologian, karttakeppipedagogian tai puisevan teoriapitoisen luennoinnin kautta. Tarvittiin yhteisöllisyyttä ja opistodemokratiaa. Eri aineiden opiskelijat ja opettajat tuli saada saman opistolaisyhteisön jäseniksi. Tavoitetta tukivat opistolaisneuvostot, toverikunnat, opistolaisyhdistykset, iltamat, kesäkodit, retket ja yhteisjärjestöt.

Opistolaisuuden tavoite näkyi hyvin vuonna 1919 perustetun Työväenopistojen liiton toiminnassa: alusta alkaen mukana olivat niin opistojen omistajat, opettajat kuin oppilaatkin. Liiton kokouksissa istui näin samoissa pöydissä kunnanvaltuustojen porvaristoa, sivistyneistön edustajia ja työväestöä.

Yhteiskunnallista dialogia ja siihen tarvittavia kansalaistaitoja opiskeltiin lisäksi omana oppiaineenaan. Aina 1960-luvulle saakka opistojen suosituimpia opintoryhmiä olivat keskustelupiirit, jotka esimerkiksi Helsingin työväenopistossa vetivät salit täyteen vuosien ajan. 
Vuoden 1922 opetusohjelmassaan työväenopisto esitteli keskustelupiirin toteamalla, että tavoite oli "perehdyttää opistolaisia kokoustenpitoon ja keskustelutaitoon sekä ylläpitää toveriyhteyttä opiskelijain keskuudessa”. Piirin vetäjänä toimi opiston johtaja, mutta kokouksien puheenjohtajana ja sihteerinä toimi aina joku piirin jäsen. Yksi opiskelija tai vieraileva luennoija alusti aina jostain ajankohtaisesta aiheesta, minkä jälkeen kuultiin ensin piiriläisistä valitun opponentin puheenvuoro, ja lopuksi koko piiri osallistui keskusteluun. Kokouksesta tehtiin pöytäkirja ja keskusteluista laadittiin kuvaukset piirin omaan lehteen. Lisäksi piiri järjesti kerran kuukaudessa "ohjelmallisen seurustelu- ja juhlaillan".

Aikalaismuistelmissa opintopiirien "kokousten" kerrotaan olleen monesti erittäin keskustelevia, ja ajoittain kokouksissa käsitelleiden aiheiden herättäneen suuria tunteita. Jos keskustelu oli karata puheenjohtajan käsistä, opintopiirien kokouksia rauhoitettiin yhteislaululla. Parin reippaan laulun jälkeen kuumimmat tunteet olivat laimentuneet, ja keskustelua voitiin jatkaa.

\section{UUDEN AJAN YHTEISÖLLISYYYS}

Ensimmäisten vuosikymmenien ajan vapaa sivistystyö edisti siis tietoisesti sekä suoraan että epäsuorasti kansallista dialogia ja eri yhteiskuntaryhmien kansalaistaitojen kehittymistä. Entä miten on nyt? Lain mukaan

"Vapaan sivistystyön tarkoituksena on järjestää elinikäisen oppimisen periaatteen pohjalta yhteiskunnan eheyttä, tasa-arvoa ja aktiivista kansalaisuutta tukevaa koulutusta. Vapaana sivistystyönä järjestettävän koulutuksen tavoitteena on edistää ihmisten monipuolista kehittymistä, hyvinvointia sekä kansanvaltaisuuden, moniarvoisuuden, kestävän kehityksen, monikulttuurisuuden ja kansainvälisyyden toteutumista. Vapaassa sivistystyössä korostuu omaehtoinen oppiminen, yhteisöllisyys ja osallisuus."

Tavoitteet ovat säilyneet ennallaan, vaikka avainkäsite - 'sivistys' - onkin korvattu konkreettisemmilla määritteillä.

Vapaa sivistystyö on ollut 1990-luvun alkuvuosista lähtien suurissa muutoksissa, jotka ovat pääosin olleet sidoksissa laajemmin yhteiskunnan muuttumiseen.
Kansalaisten koulutustason nousu on tehnyt opistoista yhä enemmän luovuuden ja lisäopintojen mahdollistajia kuin kansalaiskasvattajia. Opistoille julkisessa keskustelussa asetetuissa tavoitteissa ja toimialan omassa viestinnässä on aiempaa enemmän nostettu esiin toiminnan suoria hyötyjä niin yksilöille kuin kansantaloudelle. Opistot ovat pitäneet roolinsa kansalaistaitojen välittäjinä: ikäihmisille tarjotaan tietotekniikan opetusta, ja maahanmuuttajia kotoutetaan.

Modernin ajan yhteisöllisyydestä on siirrytty jälkiteollisen ajan yksilöllisyyteen. Juhlat, opistolaisyhdistykset ja kesäkodit alkavat olla historiaa. Koko opiston yhdistävän yhteisöllisyyden ovat korvanneet kurssien ja ryhmien omat kokoontumiset ja someryhmät.

Toiminta luokkahuoneissa on samanlaista kuin vapaan sivistystyön ensimmäisen sadan vuoden aikana, mutta toiminta luokkahuoneiden ulkopuolelta on muuttunut täysin. Modernin ajan yhteisöllisyyden varaan rakentunut sivistystyö on menettänyt toimintaedellytyksensä. Opistolaiset eivät enää ole opistolaisia vaan enemmänkin opiskeluryhmänsä jäseniä. Heidän taustansa ovat aiempaa moninaisempia: samassa teatteriryhmässä tai käsityökurssilla saattaa olla osallistujia vauvasta vaariin ja kouluja käymättömistä maahanmuuttajista emeritusprofessoreihin. Mikrotasolla tapahtuu sama kuin se, mitä aiemmin haettiin opistolaisuuden nimissä.

Vapaan sivistystyön ensimmäisten vuosikymmenien keskustelupiirit ovat katoavaa opistolaisperinnettä. Kansallisen dialogin harjoittelu suurissa opintopiireissä ei enää saa suomalaisia liikkeelle. Tarve yhteisen keskustelun opettelulle ei kuitenkaan ole kadonnut. Someaika on nostanut uudelleen ja aiempaa voimakkaammin esiin vihapuheen, kuplat ja monenlaisia toiseuden sietämisen ongelmat.

Opistolaisliikkeen satavuotisjuhlan tavoitteeksi sopisi uudenlainen someajan keskustelupiiri. Tarvetta sille ainakin olisi.

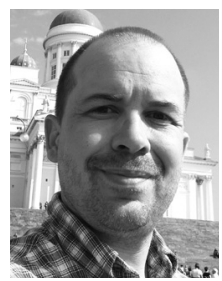

SAMU NYSTRÖM

FT, Suomen ja Pohjoismaiden historian dosentti Helsingin yliopisto 